\title{
NEW RECORD OF THE ATLANTIC POMFRET Brama brama (Bonnaterre, 1788) (SCOMBRIFORMES: BRAMIDAE) FOR GHAZAOUET BAY, WESTERN MEDITERRANEAN SEA
}

\begin{abstract}
Lotfi Bensahla-Talet (iD
University Oran1-Ahmed BENBELLA, Faculty of Natural Sciences and Life. Department of Biology, Laboratory of Aquaculture and Bioremediation (AQUABIOR). 31000 Oran-Algeria

*Corresponding Author: btlotfi1977@gmail.com

ABSTRACT

The present paper reports the first record of the Atlantic pomfret Brama brama for western Algerian waters in the Western Mediterranean Sea. It is a high migratory species, rarely met in Algerian fisheries. One specimen of B. brama was caught by a seiner operating in Ghazaouet Bay on September $6^{\text {th }} 2018$, measuring $672.5 \mathrm{~mm}$ of standard length (SL), and weighting 4,740 grams (g), constituting the new maximum length recorded for the species in the Mediterranean Sea. Accordingly, we describe biometrical and meristic characteristics, literature, databases and fish collections review of this bramid, firstly record for the Algerian waters.

Keywords: Algeria, bramid, morphometrics, new occurrence.
\end{abstract}

\section{RESUMO}

O presente artigo consiste no primeiro registro da da espécie palombeta Brama brama para a águas do mar Mediterrâneo ocidental na Argélia. É uma espécie altamente migratória, mas raramente encontrada nas peixarias da Argélia. Um espécime de B. brama foi capturado por um pescador que operava na Baía de Ghazaouet em setembro 2018, o exemplar obtido mediu $672,5 \mathrm{~mm}$ de comprimento padrão e pesou $4.740 \mathrm{~g}$, constituindo no novo comprimento máximo registrado para a espécie no mar Mediterrâneo. Desta forma, apresentamos as características biométricas e merísticas, revisão de literatura, bancos de dados e revisão de coleções do primeiro registro dessa espécie de bramídico em águas argelinas. Palavras-chave: Argélia, bramídeo, morfometria, nova ocorrência.
\end{abstract}

Brama brama (Bonnaterre, 1788) is a pelagic neritic and oceandromous species occurring at depths ranging from 0 to 1,000 meters $(\mathrm{m})$, usual between 0 and $200 \mathrm{~m}$, occasionally coming close to the shore (Smith, 1986). It lives in temperatures ranging from $12^{\circ} \mathrm{C}$ to $24^{\circ} \mathrm{C}$, being a seasonal migrant species, occurring in small schools performing movements apparently related to the water temperature (Mead \& Haedrich, 1965; Kells \& Carpenter, 2011). This species usually feeds on small fishes, cephalopods, amphipods, and euphausiids (Haedrich, 1986).

This species possesses a widespread distribution, occurring along the Atlantic, Indian and South Pacific oceans, from $65^{\circ} \mathrm{N}$ to $70^{\circ} \mathrm{S}$, and from $180^{\circ} \mathrm{W}$ to $180^{\circ} \mathrm{E}$ (McMillan et al. 2011). In Western Atlantic it is distributed from Nova Scotia, Canada and Bermuda (Robins \& Ray, 1986) to Belize and the Antilles (Claro, 1994). It can also be found in Brazil and in Argentine (Menni et al. 1984), and lives from zero to $400 \mathrm{~m}$ depth in northern continent from Cape Cod (39 $\left.58^{\prime} \mathrm{N}, 70^{\circ} 46^{\prime} \mathrm{W}\right)$ to the Grand Banks of newfoundland, Canada and south to northern South America (Scott \& Scott. 1988; Moore et al.
2003). In the Eastern Atlantic, B. brama occurs from central Norway to Algoa Bay, in South Africa. For West African coasts, it ranges from Morocco $\left(30^{\circ} \mathrm{N}\right)$ to South Africa $\left(35^{\circ} \mathrm{S}\right)$ (Haedrich, 2016 in Carpenter \& De Angelis, 2016). This species ranges from Walvis Bay, in Namibia, to the extreme south around the Cape of Good Hope to Algoa Bay, in South Africa, in depths from 50 to $1,000 \mathrm{~m}$, rarely occurring near land (Heemstra \& Heemstra, 2004). It could also be found in Pacific Ocean: in Australia (May \& Maxwell, 1986) and New Zealand (Paulin et al., 1989).

The Atlantic pomfret is a cosmopolitan and highly migratory oceanic and epipelagic species. It is generally found on the continental slope (at depths down to 1000m) (Bianchi et al. 1993). In the Northeast Atlantic and western Mediterranean, $B$. brama is targeted as a seasonally important fisheries resource in semi-pelagic longline fisheries in Galicia (northwestern Spain), in Portugal and off northwest Africa (Lobo \& Erzini, 2001). In Spain Brama brama has a great economic importance, being generally 
marketed fresh (Pérez-Alonso et al. 2004). It also has been used as a replacement for higher-cost species in the production of smoked fish products (PérezAlonso et al. 2003). In a majority of fisheries this bramid is taken as bycatch, which is the case of south coast of Portugal, where B. brama is the second most abundant commercial species in the hake (Merluccius merluccius Linnaeus, 1758) fishery (Erzini et al., 2001). It is also taken as bycatch in legal and illegal tuna driftnet fisheries (Bănaru et al., 2010).

Heemstra \& Heemstra (2004) and Quigley (2008) argued that B. brama is a pelagic offshore species constituting an important prey item to large marine predators as tunas, mackerels and marlins. Despite its commercial importance, relatively little is known about the species' population dynamics. Although the species was first recorded for Irish waters in 1843 , it was still regarded as scarce up until the late 1950s, but between 1960s and 1970s large numbers were recorded. Nevertheless, the species would appear to have made a comeback between 2003 and 2007, with increasingly significant quantities landed by commercial long-liners off the west coast. Significant numbers have been found stranded on North Sea coasts, possibly due to disorientation caused by decreasing water temperatures $\left(<13^{\circ} \mathrm{C}\right)$ (Quigley, 2008). The vast majority $(>80 \%)$ of Ray's Bream recorded in Irish waters have been taken by commercial trawlers, and specimens were taken near the surface with feather/ mackerel/jigs during the hours of darkness (Quigley, 2008). In Eastern Atlantic (Galicia, NW Spain) Rodriguez, 1980 noticed the same phenomenon between 1969 and 1975 that $B$. brama became scarce and fleet was obliged to move to the North-West coasts of Africa. To evaluate population trends a first attempt was leaded by IUCN experts (Quignard et al., 2011) and concluded that the species is data deficient then a second report in 2015 concluded that the species is classified as LC (Least Concern) with a decline in mature individuals (Colette et al., 2015).
Brama brama is not directly targeted by fishing gears but can be a by-catch of semi-industrial fishing, purse seines, trawls, gillnets, bottom longlines, drifting longlines, it is also a Least Concern (LC) species on the IUCN Red List (ver 3.1) (Iwamoto et al. 2015). Many documents dealing with this species are available in the literature, such as: age and growth (Lobo \& Erzini, 2001; Paul et al. 2004; Hermas et al. 2019); occurrence and fisheries (Mead \& Haedrich, 1965; Boyd, 1970; Williams, 1977; Quigley, 2008; Quigley \& Flannery, 2008; Quero et al. 2009; Garibaldi, 2015; Anastasopoulou et al. 2016; Bolshakova \& Evseenko, 2016; Masski \& Ait Hammou, 2016; Mafwila, 2017; Akyol et al. 2019); bioecology and behavior (Rodriguez, 1980; Dulčić, 1999; Richards, 2003; Hanel \& John, 2014; Quinzán et al. 2016); pollution (Neves et al., 2015; Strbac et al., 2015; Dione et al., 2018); parasites (LlarenaReino et al., 2015); and food process (Pérez-Alonso et al., 2003; Pérez-Alonso et al., 2004); but up to date there are no works reporting this species for Algerian waters.

On $6^{\text {th }}$ September 2018 a single specimen of $B$. brama (Figure 1) was caught by a seiner in Ghazaouet Bay (35'06'18.4'N 1'51'26.7'W) (Figure 2), in the western Algerian coast. Thirteen morphometric characteristics were made adapted from Akyol et al. (2019) (Table 1). The measures were carried out using a digital caliper to the nearest $0.01 \mathrm{~mm}$.

FAO identification sheets (Gomes, 1990; Haedrich, 2016) was used to identify the specimen as Brama brama (Figure 1), and morphometric characteristics are summarized in Table 1. The species is characterized by having: a moderate body height and somewhat compressed; head very compressed with very convex back profile; very rounded interorbital space; large oblique mouth; wide and scaly maxillary extending at least up to the middle of the eye; lower edge of the mandibles in close contact on the ventral median line behind the symphysis, the isthmus not being visible between

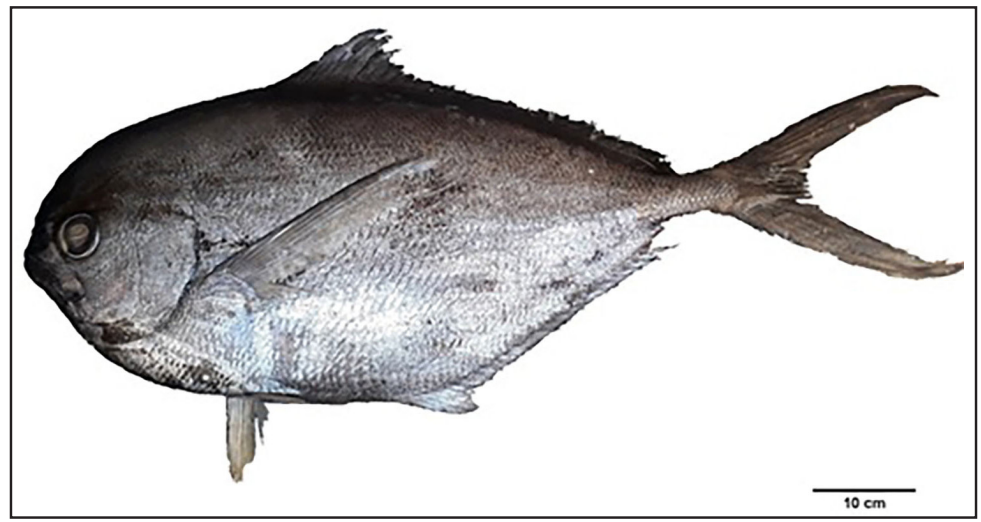

Figure 1. Specimen of Brama brama $(672.5 \mathrm{~mm} \mathrm{SL})$ collected in Ghazaouet Bay, Algeria. Photographed by L. Bensahla-Talet. 


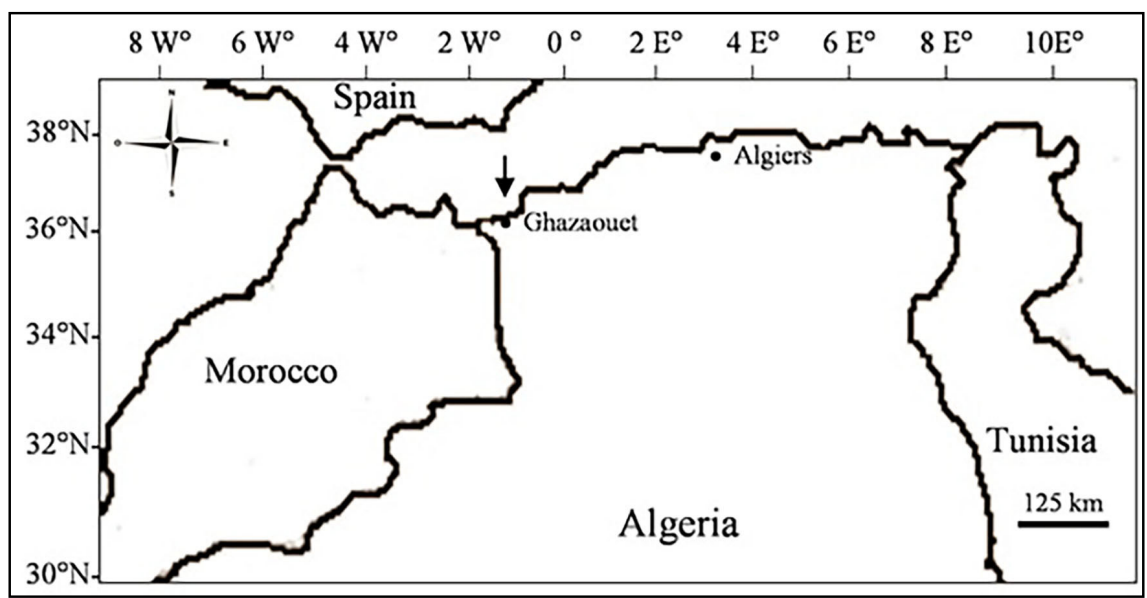

Figure 2. Localization of sampling zone (Ghazaouet Bay), western Algerian coast, Mediterranean Sea. The arrow indicates the location where the specimen was collected.

Table 1. Morphometric measurements in mm of the specimen of Brama brama.

\begin{tabular}{|c|c|c|c|}
\hline \multicolumn{2}{|c|}{ Morphometrical characteristic } & \multirow{2}{*}{$\frac{\text { Measurement (mm) }}{850.53}$} & \multirow{2}{*}{$\frac{\% \text { of SL }}{126.46}$} \\
\hline TL & Total length & & \\
\hline FL & Fork length & 720.47 & 107.12 \\
\hline SL & Standard length & 672.57 & 100.00 \\
\hline POD1 & Pre ocular distance & 33.54 & 4.99 \\
\hline ED & Eye diameter & 38.27 & 5.69 \\
\hline POD2 & Post ocular distance & 90.02 & 13.38 \\
\hline $\mathbf{H}$ & Head length & 165.42 & 24.60 \\
\hline Dfl & Dorsal fin length & 370.64 & 55.11 \\
\hline Afl & Anal fin length & 296.18 & 44.04 \\
\hline Vff & Ventral fin length & 62.80 & 9.34 \\
\hline Pfl & Pectoral fin length & 237.47 & 35.31 \\
\hline Hmin & Minimum body height & 42.00 & 6.24 \\
\hline \multirow[t]{2}{*}{ Hmax } & Maximum body height & 297.16 & 44.18 \\
\hline & & \multicolumn{2}{|c|}{ Meristic characters } \\
\hline Dorsal fin ray & & \multicolumn{2}{|c|}{36} \\
\hline Anal fin rays & & \multicolumn{2}{|c|}{28} \\
\hline Pectoral fin $r$ & & \multicolumn{2}{|c|}{20} \\
\hline Ventral fin ra & & \multicolumn{2}{|c|}{8} \\
\hline $\begin{array}{l}\text { Scales rows } \\
\text { Scales of late }\end{array}$ & & \multicolumn{2}{|c|}{46} \\
\hline
\end{tabular}

them; pectoral fins extending beyond the lobe of the anal; pelvic fin inserted under the base of the pectorals or slightly further back and surmounted by a large axillary scale; lateral line barely visible in adults; smooth scales, with unequal edges, covering the head, the body and extending on the odd fins; and a coloration characterized by a silvery black, odd fins slightly lighter (Gomes, 1990; Haedrich, 2016).
Brama brama can easily be misidentified with a similar species occurring in the same area named the lesser bream, Brama dussumieri Cuvier, 1831, which presents 19 to 21 pectoral-fin rays (usually 22), 35 to 38 dorsal-fin rays, 29 to 32 anal-fin rays, 15 to 18 gill rakers on first arch, 70 to 80 lateral-line scales with a maximum length not exceeding $37 \mathrm{~cm}$ of total length; while $B$. brama presents 19 to 21 pectoral-fin 
rays (usually 20), 33 to 35 dorsal-fin rays, 26 to 28 anal-fin rays, 13 to 15 gill rakers on first arch, 57 to 65 lateral-line scales (Haedrich, 2016) with a maximum length of $101 \mathrm{~cm}$ of total length (Claro, 1994) and a maximum weight of $6 \mathrm{~kg}$ (Muus \& Dahlström, 1978).

Brama brama is rare in the Mediterranean Sea (Bauchot, 1987; Quignard et al. 2011). It was reported for: the Eastern Mediterranean by Bilecenoglu et al. (2002), Golani et al. (2005), Akyol \& Ulaş (2019); the Central Mediterranean by Dulčić et al. (1999, 2003), Corsini-Foka (2009), Mytilineou et al. (2013), Garibaldi et al. (2015), Anastasopoulou et al. (2016), Elbaraasi et al. (2019); and the Western Mediterranean by Quero et al. (2008), Ranz (2017) where it seems to be concentrated in Balearic Sea (GBIF, 2020; OBIS, 2020). However, there are no records for North African waters nor for Algerian waters.

According to Mead (1972), B. brama has specific temperature requirements. Quinzán et al. (2016) unveiled the influence of the environment on the migration pattern of the Atlantic pomfret (Brama brama), and obseved that during years with cooler surface waters the Atlantic pomfret is only available in restricted areas and yields are low while large migrations are observed in scenarios of high SSTs in the migratory area (above $14.7^{\circ} \mathrm{C}$ ). Migrations, however, are constrained during years when temperatures are below this threshold. Migration is often driven by biological needs such as reproduction and food but is also often constrained by climate variability.

Occhipinti-Ambrogi \& Galil (2010) argued that climate changes facilitate overcoming historic geographic barriers. Although, recent increases, over the last thirty years, in the sea surface temperature (SST) of the Canary Islands area, with records over $24^{\circ} \mathrm{C}$, can be observed, influencing the distribution of the species (Santos et al. 2012) due to global warming (Walther et al., 2002; Parmesan, 2006; GonzálezLorenzo et al., 2013). Moullec et al. (2016) have noticed the same phenomenon in the Mediterranean basin and deducted that temperature has a major direct effect on the physiology, growth, reproduction, recruitment and behavior of poikilothermic organisms such as fishes. The warming of the Mediterranean Sea affects the fitness of marine biota as already shown by records of changes in abundance, survival and fertility, phenology and species migration (Marbà et al. 2015).

This first record of B. brama in western Algerian waters can be explained by the fact that Algerian waters are located at the entrance of Gibraltar strait, being the second point after the first one in Morocco (Masski \& Hammou, 2016), since the whole trajectory of this high migratory bramid movement is highly influenced by elevated water temperatures in this period of the year (Mead,1972). Consistent studies should be leaded to retrace real migratory pathway of this species and explain why its unusual presence is scattered throughout the Mediterranean basin, and at the same time concentrated around the Balearic Islands. It is also concluded whether this presence in the Mediterranean was not influenced only by temperature fluctuations, but also by other environmental factors namely nutritional or physiological needs such as the search for new spawning grounds for the species.

The largest specimen of B. brama ever reported was in Cuba (Claro, 1994) with 1,010 mm TL and with $6000 \mathrm{~g}$, while the largest specimen in the Mediterranean was recorded in Greek waters of the southern Aegean Sea, with $700 \mathrm{~mm}$ TL and 4,500 g (Corsini-Foka, 2009). In the Eastern Ionian Sea, Mytilineou et al. (2013) reported the largest specimen, measuring $643 \mathrm{~mm}$ TL and with 3,638 g; and in the Eastern Adriatic Sea Dulčič et al. (2003) reported a specimen measuring 4,062 $\mathrm{mm}$ TL and weighting $6,442 \mathrm{~g}$. Recently, a specimen with 710 $\mathrm{mm}$ TL and 5,696 $\mathrm{g}$ was caught in Turkish waters (Akyol \& Ulaş, 2019). Our specimen collected in Ghazaouet Bay has $850.5 \mathrm{~mm}$ TL and 4,740 g, constituting the new maximum record for the species in the Mediterranean Sea.

\section{ACKNOWLEDGMENTS}

We thank the fishermen of "Ghazaouet fishery", and especially $\mathrm{M}^{\mathrm{r}}$.Mokhtar for informing us about the capture of this rare specimen.

\section{REFERENCES}

AKYOL, O. \& ULAŞ, A. 2019. Occurrence of the Atlantic pomfret, Brama brama (Bonnaterre 1788) (Perciformes: Bramidae) in the Aegean Sea (Siğacik Bay, Turkey). Aquat. Res. 2 (1): 32-35.

ANASTASOPOULOU, A., BIANDOLINO, F., CHATZISPYROU, A., HEMIDA, F., GUIJARRO, B., KOUSTENI, V., MYTILINEOU, C.H. \& PRATO, E. 2016. New Fisheries-related data from the Mediterranean Sea (November, 2016). Medit. Mar. Sci, 17(3), 822-827. doi:10.12681/mms.1909

BĂNARU, D., DEKEYSER, I., IMBERT, G. \& LAUBIER L. 2010. Non-target and released alive 
by-catch distributions observed during French driftnet fishery in the Northwestern Mediterranean Sea (2000-2003 database). J. Oceanogr. Res. Data 3: 33-45.

BAUCHOT, M. L. 1987. Poissons osseux. p. 8911421. In W. Fischer, M.L. Bauchot and M. Schneider (eds.) Fiches FAO d'identification pour les besoins de la pêche. (rev. 1). Méditerranée et mer Noire. Zone de pêche 37. Vol. II. Commission des Communautés Européennes and FAO, Rome.

BIANCHI, G., CARPENTER, K. E., ROUX, J. P., MOLLOY, F. J., BOYER, D. \& BOYER, H. J. 1993. FAO species identification field guide for fishery purposes. The living marine resources of Namibia. FAO, Rome.

BILECENOGLU, M., TASKAVAK, E., MATER, S., \& KAYA, M. 2002. Checklist of the marine fishes of Turkey. Zootaxa, 113(1), 1-194.

BOLSHAKOVA, Y. Y. \& EVSEENKO, S. A. 2016. On species composition of ichthyoplankton of the Mid-Atlantic Ridge (South Atlantic). J. Ichthyol, 56(4), 522-533. doi: 10.1134/S0032945216040020

BONNATERRE, P. J. 1788. Tableau encyclopédique et méthodique des trois règnes de la nature. Ichthyologie. - pp. i-lvj [= 1-66], 1-215. Paris. (Panckoucke).

BOYD, R. J. 1970. A Ray's Bream, Brama brama (Bonnaterre), Found Stranded in Belfast Lough. Ir. Nat.' J., 313-314.

CARPENTER, K. E. \& DE ANGELIS, N. (EDS.) 2016. The living marine resources of the Eastern Central Atlantic. Volume 4. Bony fishes part 2 (Perciformes to Tetraodontiformes) and Sea turtles. FAO Species Identification Guide for Fishery Purposes, Rome, FAO. [Orders and families by individual authors.]. i-xiii + 2343-3124.

CLARO, R. 1994. Características generales de la ictiofauna. p. 55-70. In R. Claro (ed.) Ecología de los peces marinos de Cuba. Instituto de Oceanología Academia de Ciencias de Cuba and Centro de Investigaciones de Quintana Roo.

CORSINI-FOKA, M. 2009. Uncommon fishes from Rhodes and nearby marine region (SE Aegean Sea, Greece). J. Biol. Res-Thessaloniki, 12, 125-133.

DIONE, C. T., DIAGNE, I., NDIAYE, M., DIEBAKATE, C., NDIAYE, B. \& DIOP, A. 2018. Contamination Métallique D'une Espèce De Poisson (Brama Brama) De La Côte Dakaroise. Eur. Sci. J,
ESJ, 14(12). doi: 10.19044/esj.2018.v14n12p374

DULČIĆ, J. 1999. First record of larval Brama brama (Pisces: Bramidae) and Corphaena hippurus (Pisces: Coryphaenidae) in the Adriatic Sea. $J$. Plankton. Res, 21(6).

DULČIĆ, J., PALLAORO, A., ONOFRI, V., LUČIĆ, D., JARDAS, I. 2003. New additional records of Imperial blackfish, Schedophilus ovalis (Cuvier, 1833), White trevally, Pseudocaranx dentex (Bloch \& Schneider, 1801), and Atlantic pomfret, Brama brama (Bonnaterre, 1788), in the eastern Adriatic. Ann. Ser. Hist. Nat., volume 13, issue 2, str. 149-154.

ELBARAASI, H., ELABAR, B., ELAABIDI S., BASHIR A., ELSILINI O., SHAKMAN, E. \& AZZURRO, E. 2019. Updated checklist of bony fishes along the Libyan coast (southern Mediterranean Sea). Mediterr. Mar. Sci. 20 (1): 90-105.

ERZINI, K., GONÇALVES, J.M.S, BENTES, L., LINO, P.G. \& RIBEIRO, J. 2001. The hake deepwater semi-pelagic ("pedra-bola") longline fishery in the Algarve (southern Portugal). Fish. Res. 51: $325-334$.

FRICKE, R., BILECENOĞLU, M. \& SARI, H. M. 2007. Annotated checklist of fish and lamprey species (Gnathostomata and Petromyzontomorphi) of Turkey, including a Red List of threatened and declining species. Stuttg. Beitr. Naturkd., A (Biologie). 706: 1-169.

GARIBALDI, F. 2015. By-catch in the mesopelagic swordfish longline fishery in the Ligurian Sea (Western Mediterranean). Collect. Vol. Sci. Pap. ICCAT, 71(3), 1495-1498.

GONZÁLEZ-LORENZO, G., GONZÁLEZ JIMÉNEZ, J. F., BRITO, A. \& GONZÁLEZ, J. A. 2013. The family Bramidae (Perciformes) from the Canary Islands (northeastern Atlantic Ocean), with three new records. Cybium. 37(4): 295-303.

GBIF. 2019. Brama brama (Bonnaterre, 1788) GBIF Backbone Taxonomy. Checklist dataset https:/doi. org/10.15468/39omei accessed via GBIF.org on 2020-03-21.

GOLANI, D. 2005. Checklist of the Mediterranean fishes of Israel. Zootaxa 947: 1-90.

GOMES, J., 1990. Bramidae. p. 758-764. In J.C. Quero, J.C. Hureau, C. Karrer, A. Post and L. Saldanha (eds.) Check-list of the fishes of the eastern tropical Atlantic (CLOFETA). JNCT, Lisbon; SEI, Paris; and UNESCO, Paris. Vol. 2. 
HAEDRICH, R. L. 1986. Bramidae. p. 847-853. In WHITEHEAD, P.J.P. BAUCHOT M. L., HUREAU, J.C., NIELSEN, J. \& TORTONESE, E. (eds.) Fishes of the north-eastern Atlantic and the Mediterranean. UNESCO, Paris. Vol. 2.

HANEL, R. \& JOHN, H. C. 2014. A revised checklist of Cape Verde Islands sea fishes. J. App. Ichthyol, 31(1), 135-169. doi: 10.1111/jai.12621

HEEMSTRA, P. C. \& HEEMSTRA, E. 2004. Coastal fishes of southern Africa. NISC (PTY) LTD.

HERMAS, D., EL GOUMRI, Y., ELBAHI, A., HAFIDI, N \& KAYAA, A. 2019. Age and growth of ray's bream: Brama brama (bonnaterre, 1788) From the south Atlantic coast of morocco. International Journal of Agriculture, Environment and Bioresearch 4, (03):234-241. doi: 10.35410/IJAEB.2019.234241

IWAMOTO, T., SINGH-RENTON, S., ROBERTSON, R., MARECHAL, J., AIKEN, K. A., DOOLEY, J., COLLETTE, B. B., OXENFORD, H., PINA AMARGOS, F. \& KISHORE, R. 2015. Brama brama. The IUCN Red List of Threatened Species 2015: e.T195091A19929350. http://dx.doi.org/10.2305/IUCN.UK.20154.RLTS. T195091A19929350.en. Downloaded on 12 September 2018.

KELLS, V. A. \& CARPENTER, K. 2011. A field guide to coastal fishes: from Maine to Texas. JHU Press.

LLARENA-REINO, M., ABOLLO, E., REGUEIRA, M., RODRÍGUEZ, H. \& PASCUAL, S. 2015. Horizon scanning for management of emerging parasitic infections in fishery products. Food Control, 49, 49-58.

LOBO, C. \& ERZINI, K. 2001. Age and growth of Ray's bream (Brama brama) from the south of Portugal. Fish. Res, 51(2-3), 343-347.

MAFWILA, S. K. 2017. The community structure of demersal fish species from bottom-trawls off Namibia and the West coast of South Africa. Int. J. Life Sci, 5(2), 180-188.

MARBÀ, N., JORDÀ, G., AGUSTÍ, S., GIRARD, C. \& DUARTE, C. M. 2015. Footprints of climate change on Mediterranean Sea biota. Front. Mar. Sci., 2, 56.

MASSKI, H. \& AIT HAMMOU, A. 2016. Naming Moroccan fish: when diversity faces standardisation imperatives. J. App. Ichthyol, 32(5), 873-882. doi: 10.1111/jai.13098
MASUDA, H., AMAOKA, K., ARAGA, C., UYENO, T. \& YOSHINO, T. 1984. The fishes of the Japanese Archipelago. Vol. 1. Tokai University Press, Tokyo, Japan. 437 p.

MAY, J. L. \& MAXWELL, J. G. H. 1986. Trawl fish from temperate waters of Australia. CSIRO Division of Fisheries Research, Tasmania. 492 p.

MCMILLAN, P. J., FRANCIS, M. P., JAMES, G. D., PAUL, L. J., MARRIOTT P. J, MACKAY E., WOOD B. A., GRIGGS, L. H., SUI, H. \& WEI, F. 2011. New Zealand fishes. Volume 1: A field guide to common species caught by bottom and midwater fishing. New Zealand Aquatic Environment and Biodiversity Report No. 68. 329 p.

MEAD, G. W. \& HAEDRICH, R. L., 1965. The distribution of the oceanic fish Brama brama. Bull. Nhis. Comp. Zool., 134(2): 29-68, June, 1965.

MEAD, G. W. 1972. Bramidae. The Carlsberg Foundation's oceanographical expedition round the World 1928-30 and previous Dana-expeditions. Dana-Report, 1-166.

MENNI, R. C., RINGUELET R. A. \& ARAMBURU, R. H. 1984. Peces marinos de la Argentina y Uruguay. Editorial Hemisferio Sur S.A. Buenos, Aires, Argentina. 359 p.

MYTILINEOU, C., ANASTASOPOULOU, A., CHRISTIDES, G., BEKAS, P., SMITH, C. J., PAPADOPOULOU, K.N., LEFKADITOU, E. \& KAVADAS, S. 2013. New records of rare deep-water fish species in the Eastern Ionian Sea (Mediterranean Sea). J. Nat. Hist, 47(25-28), 1645-1662.

MOORE, J. A., HARTEL, K. E., CRADDOCK, J. E. \& GALBRAITH, J. K. 2003. An annotated list of deepwater fishes from off the New England region, with new area records. Northeast. Nat, 10 ( 2): $159-248$.

MOULLEC, F., BEN RAIS LASRAM, F., COLL, M., GUilhaumon, F., HALOUANi, G. \& HATTAB, T. 2016. Climate change impacts on marine resources: From individual to ecosystem responses In The Mediterranean Region under Climate Change: A Scientific Update IRD Éditions/ AllEnvi (2016) Marseille. 2(1.3): 229-248.

MUUS, B. \& DAHLSTRÖM, P. 1978. Meeresfische der Ostsee, der Nordsee, des Atlantiks. BLV Verlagsgesellschaft, München. 244 p.

MUUS, B. J. \& NIELSEN, J. G. 1999. Sea fish. Scandinavian Fishing Year Book, Hedehusene, 
Denmark. 340 p.

NEIRA, F. J., MISKIEWICZ, A. G. \& TRNSKI, T. 1998. Larvae of temperate Australian fishes: laboratory guide for larval fish identification. University of Western Australia Press. 474 p.

NEVES, D., SOBRAL, P., FERREIRA, J. L. \& PEREIRA, T. 2015. Ingestion of microplastics by commercial fish off the Portuguese coast. Mar. Poll. Bull, 101(1), 119-126. doi:10.1016/j. marpolbul.2015.11.008

OBIS. 2020. Distribution records of Brama brama (Bonnaterre, 1788). Ocean Biogeographic Information System. Intergovernmental Oceanographic Commission of UNESCO. accessed via www.iobis.org on 2020-03-21.

OCCHIPINTI-AMBROGI, A. \& GALIL, B. 2010. Marine alien species as an aspect of global change. Adv. Oceanogr. Limnol, 1(1), 199-218.

PARMESAN, C. 2006. Ecological and evolutionary responses to recent climate change, Annu. Rev. Ecol. Evol. Syst. 37 (2006), pp. 637-669.

PAUL, L. J., FRANCIS, M. \& MAOLAGÁIN C. O. 2004. Growth rate, age at maturity, longevity, and natural mortality rate of Ray's bream (Brama $s p$.). Final Research Report for Ministry of Fisheries Research Project TUN2003/01 Objective 2. National Institute of Water and Atmospheric Research Limited (NIWA). 29 September 2004.

PAUlin, C., STEWART, A., ROBERTS, C. \& MCMILLAN, P. 1989. New Zealand fish. A complete guide. National Museum of New Zealand Miscellaneous Series No. 19. 279 p.

PAVLOV, Y. P. 1991. Information on morphometrics and ecology of pomfrets of the genus Brama inhabiting the southeastern Pacific Ocean. J. Ichthyol. 31(2):120-123.

PÉREZ-ALONSO, F., ARIAS, C. \& AUBOURG, S. P. 2003. Lipid deterioration during chilled storage of Atlantic pomfret (Brama brama). Eur. J. Lip. Sci. Tech, 105(11), 661-667.

PÉREZ-Alonso, F., AUBOURG, S. P., RODRÍGUEZ, Ó. \& BARROS-VELÁZQUEZ, J. 2004. Shelf life extension of Atlantic pomfret (Brama brama) fillets by packaging under a vacuum-skin system. Eur. Food. Res. Tech, 218(4), 313-317. September 2004. doi: 10.1007/s00217-003-0831-z

QUERO, J. C., SPITZ, J., VAYNE, J. J., AUBY, I., CASAMAJOR, D., LEAUTE, J. P., MARIE,
F., MONHUREL, L. \& QUINQUIS, J. 2009. Observations ichtyologiques effectuées en 2008. In Ann. Soc. Sci. Nat. Charente-Maritime, 2009,9(9) : 932-940

QUIGLEY, D. T. 2008. Pomfrets (Bramidae) in Irish and Northern European Waters. In Sherkın Comment. Environmental Quarterly of Sherkin Island Marine Station. Issue No. 45, 8:1-31.

QUIGLEY, D. T. G. \& FLANNERY, K. 2008. Notes on some uncommon and unusual fishes recorded between 1988 and 2007. Ir. Nat.' J, 29, 60-65.

QUIGNARD, J. P., BARICHE, M., OZTURK, B., BIZSEL, C., KARA, M. H. \& YOKES, B. 2011. Brama brama. The IUCN Red List of Threatened Species 2011: e.T195091A8941573.

QUINZÁN, M., CASTRO, J., MARÍN, M., COSTAS, G., MONSERRAT, S., AMORES, A., MASSUTI E. \& HIDALGO, M. 2016. Unveiling the influence of the environment on the migration pattern of the Atlantic pomfret (Brama brama) in North-eastern Atlantic waters. Fish. Oceanogr. 25(6), 610-623. doi:10.1111/fog.12176.

RANZ, J. 2017. Banco de Datos de la Biodiversidad de la Comunitat Valenciana. Biodiversity data bank of Generalitat Valenciana. Occurrence dataset https:// doi.org/10.15468/b4yqdy accessed via GBIF.org on 2020-03-21.

RICHARDS. W. J. 2003. Preliminary guide to the identification of the early life history stages of bramid fishes of the western central north Atlantic. NOAA. Tech. Mem. NMFS-SEFSC-500 (May 2003)

RIEDE, K. 2004. Global register of migratory species - from global to regional scales. Final Report of the R\&D-Projekt 80805 081. Federal Agency for Nature Conservation, Bonn, Germany. 329 p.

ROBINS, C. R. \& RAY G. C., 1986. A field guide to Atlantic coast fishes of North America. Houghton Mifflin Company, Boston, U.S.A. 354 p.

RODRIGUEZ, V. A. 1980. On the biology and fishery of rays bream (Brama brama). Inv. Pesq, 44(2), 241-252.

SANTOS, F., DECASTRO, M., GÓMEZGESTEIRA, M. \& ÁlVAREZ, I. 2012. Differences in coastal and oceanic SST warming rates along the Canary upwelling ecosystem from 1982 to 2010. Cont. Shelf. Res, 47, 1-6.

SCOTT, W. B. \& SCOTT M. G. 1988. Atlantic fishes of Canada. Can. J. Fish. Aquat. Sci. 219. 731 pp. 
SMITH, M. M. 1986. Bramidae. p. 633-636. In SMITH M. M. \& HEEMSTRA P. C. (eds.) Smiths' sea fishes. Springer-Verlag, Berlin.

ŠTRBAC, S., KAŠANIN-GRUBIN, M., JOVANČIĆEVIĆ, B. \& SIMONOVIĆ, P. 2015. Bioaccumulation of heavy metals and microelements in silver bream (Brama brama L.), northern pike (Esox lucius L.), sterlet (Acipenser ruthenus L.), and common carp (Cyprinus carpio L.) from Tisza River, Serbia. J. Toxicol. Env. Heal. A., 78(11), 663-665.
10.1080/15287394.2015.1023406.

WAlTher, G. R., POST, E., CONVEY, P., MENZEL, A., PARMESAN, C., BEEBEE, T.J.C., FROMENTIN, J.M., HOEGH-GULDBERG, O. \& BAIRLEIN, F. 2002. Ecological responses to recent climate change, Nature 416 (2002), pp. 389-395.

WILLIAMS, R. B. 1977. A note on Ray's bream in Norfolk. Trans. Norfolk Norwich Nat. Soc. Vol 24 Part 2 (April 1977):1-89. 